\title{
MENGATASI PERMASALAHAN USAHA KULINER TRADISIONAL DI INDONESIA
}

\author{
Antasalam Ajo \\ Program Studi Agribisnis \\ Fakultas Pertanian \\ Universitas Muhammadiyah Buton \\ Jl. Betoambari No. 36 Baubau \\ Email: antanung@gmail.com
}

\begin{abstract}
Indonesia's traditional culinary business has not reached the scale that provides prosperity for small entrepreneurs. The purpose of the study is to obtain a solution format or traditional culinary business development program to build traditional Indonesian cuisine. This research is qualitative research by collecting previous research documents assisted by ATLAS. ti software version 8. The research found internal culinary business problems such as price, service, and hygiene of products, location, resources, interests, motivation, and entrepreneurial mentality, utilization of social media, traditional management, tools, access to funds, technology, infrastructure, and market reach, and do not yet have halal certificates. Meanwhile, external problems such as an unstable economy are exacerbated by the COVID19 pandemic, global competition, preference for fast food, and competition with new entrepreneurs. Solutions or programs offered include training programs, increased added value, product variation, packaging innovation, service quality, promotion, positive interaction with consumers, and product satisfaction guarantees. Further, the courage to take risks, self-awareness in the face of change, as well as be grateful for all the favors. The government needs capital assistance, a supportive climate, good partnerships, protection, training, promotion, and equal cooperation, strengthening the creative economy, and improving community empowerment programs for example through integration with tourism.
\end{abstract}

Keywords: Problems, culinary, development program

\begin{abstract}
Abstrak
Bisnis kuliner tradisional Indonesia belum mencapai skala yang memberi kesejahteraan bagi pengusaha kecil. Tujuan kajian adalah memperoleh format solusi atau program pengembangan usaha kuliner tradisional dalam upaya membangun kuliner tradisional Indonesia. Penelitian ini adalah penelitian kualitatif dengan mengumpulkan dokumen penelitian terdahulu dibantu software Atlas.ti versi 8. Penelitian mendapatkan permasalahan internal usaha kuliner seperti harga, layanan, dan kebersihan produk, lokasi, sumber daya, minat, motivasi, dan mental wirausaha, pemanfaatan media sosial, pengelolaan masih tradisional, alat, akses dana, teknologi, infrastruktur, dan jangkauan pasar, dan belum memiliki sertifikat halal. Sedangkan permasalahan eksternal seperti ekonomi yang tidak stabil diperparah pandemi COVID-19, persaingan global, preferensi terhadap kuliner cepat saji, dan persaingan dengan pengusaha baru. Solusi atau program yang ditawarkan antara lain program pelatihan, peningkatan nilai tambah, variasi produk, inovasi kemasan, kualitas
\end{abstract}


layanan, promosi, interaksi positif dengan konsumen, dan jaminan kehahalan produk. Selain itu keberanian mengambil risiko, mawas diri menghadapi perubahan, serta mensyukuri segala nikmat. Pemerintah perlu ada bantuan modal, iklim yang menunjang, kemitraan yang baik, perlindungan, pelatihan, promosi dan kerja sama setara, penguatan ekonomi kreatif, serta peningkatan program pemberdayaan masyarakat misalnya melalui integrasi dengan kepariwisataan.

Kata kunci: Permasalahan, kuliner, program pengembangan

\section{PENDAHULUAN}

\section{Latar Belakang}

Kuliner Indonesia sangat banyak dan bertebaran di berbagai daerah. Di daerah asalnya masing-masing, kuliner mudah dikenali dan merupakan salah satu identitas rakyat (Purwaning, 2017). Jadi ikatan antara kuliner tradisional dengan rakyat pemiliknya sudah membentuk ikatan yang kuat. Meski demikian, kuliner tradisional belum menjadi salah satu komoditi masyarakat yang dapat diandalkan secara ekonomi serta memberikan kesejahteraan kepada pengusaha kecil. Meski merupakan warisan budaya (Purwaning, 2017), dan melimpah (Prayogi, 2017), namun perlu upaya pengembangan yang lebih baik lagi agar kuliner tradisional yang ada terus eksis di tengah masyarakat.

Hingga kini kuliner tradisional banyak mendapatkan perhatian dan diyakini memberi peran penting. Data yang ada (Katadata, 2018), menyebutkan bahwa Badan Ekonomi Kreatif (Bekraf) mencatat, ada 5,55 juta usaha kuliner di Indonesia, atau 67,7\% dari total 8,2 juta bisnis ekonomi kreatif pada 2018. Pertumbuhannya rerata 9,82\% dalam tujuh tahun terakhir. Data tersebut menunjukkan bahwa usaha kuliner tradisional memegang peranan penting dalam pembangunan masyarakat khususnya pada ekonomi kreatif. Sebab itu, usaha meningkatkan kesejahteraan rakyat melalui produk lokal yang dimiliki masyarakat akan terus diupayakan untuk meningkatkan nilai yang ekonomis bagi usaha masyarakat.

Mengatasi permasalahan yang ada tersebut, dibutuhkan keterlibatan semua pihak. Tujuannya adalah agar usaha kuliner mampu mendorong kesejahteraan rakyat khususnya untuk pengusaha kecil yang bergerak dalam usaha kuliner tradisional. Beberapa penelitian menyebutkan permasalahan yang dihadapi antara lain penyajian yang masih tradisional (Widowati, Hartati, dan Amirudin, 2018), belum diketahui banyak orang (Fajri, 2018), pemasaran terbatas (Ri'aeni, 2019), dan tidak terinvetarisasi atau terdata dengan baik (Sukerti, Marsiti, dan Suriani, 2016). Dari kondisi ini, dapat dikatakan pengembangan kuliner tradisional selama ini belum optimal dilaksanakan karena belum adanya suatu gambaran informasi atau pertimbangan kebijakan yang sesuai guna pengembangan lebih lanjut. Berbagai penelitian juga sudah banyak dilakukan namun perlu dirumuskan lebih lanjut agar penelitian tersebut memberi konsep yang dapat dipahami.

Hal tersebut tentu saja antara lain memicu perhatian dan mendorong diadakannya kajian ini. Namun, karena penelitian-penelitian tersebut belum tersusun sebagai satu kesatuan yang 
saling melengkapi, maka perlu dilakukan review artikel penelitian untuk membantu menangani permasalahan usaha kuliner tradisional di Indonesia yang selama ini telah ada.

Kini kuliner tradisional telah menjadi bagian ilmu yang dipelajari secara khusus di akademi gizi atau tata boga. Selain itu juga kuliner sebagai makanan untuk memenuhi kebutuhan manusia telah ada dan dikembangkan sejak lama, yang juga tidak dapat dipisahkan dengan ilmu pertanian, khususnya agribisnis. Kata kuliner atau dalam Bahasa Inggris "culinary" (Alamsyah, 2008) dikaitkan dengan masakan atau dapur, dimana ada tukang masak yang bertanggung jawab agar menyiapkan makanan sehingga terlihat menarik dan lezat. Dengan perkembangan yang ada, maka pengelolaan kuliner pun semakin maju searah dengan perkembangan ilmu pengetahuan dan teknologi.

Setiap bidang yang dibangun di tengah masyarakat selalu menghadapi berbagai permasalahan, lebih khusus terhadap kuliner ini. Permasalahan kuliner antara lain dokumentasi yang tidak jelas dan akurat tentang kuliner asli Indonesia (Sukerti et al., 2016), kebijakan yang kurang mendukung (Alamsyah, 2008), umur simpan yang pendek (Herawati, 2008), pengetahuan pemasaran yang minim (Aini, Khaudli, dan Suprapto, 2018), belum optimalnya pengembangan wisata kuliner berbasis sumber daya lokal (Prayogi, 2017), dan permasalahan mendasar lain. Ditengarai usaha kuliner terancam tidak eksis lagi (Sulastri, Hasniah, dan Suraya, 2019) bilamana tidak ditangani dengan baik dan berkelanjutan.

Situasi yang dihadapi juga menarik ditelaah. Mulai dari persaingan kuliner baik nasional dan internasional yang semakin ketat dan kompleks (Hubeis, Purwanto, dan Dewi, 2015), teknis produksi yang semakin berkembang (Hamidah, 2009), peningkatan penggunaan digital (Ri'aeni, 2019) seperti aplikasi untuk pemesanan atau pengiriman (Pamungkas, 2016), dan sebagainya. Tentu cara yang tepat untuk mengatasi berbagai masalah yang dihadapi dalam pengembangan kuliner nasional adalah perlunya solusi yang integral atau holistik sehingga upaya mengangkat kuliner tradisional menjadi produk unggulan rakyat di mana kuliner tersebut berasal bisa terwujud. Beberapa penelitian menyebutkan beberapa solusi antara lain perlunya sentuhan teknologi dan manajemen modern (Abubakar \& Palisuri, 2018), meningkatkan keunggulan kompetitif melalui peningkatan inovasi dan kewirausahaan (Lestari, Astuti, dan Ridwan, 2019), secara teknis dengan membangun aplikasi digital untuk pengembangan kuliner (Putra et al., 2020), pemetaan UKM kuliner (Giyanti \& Indriastiningsih, 2018), dan yang terkait kebijakan pemerintah misalnya melakukan integrasi usaha kuliner dengan industri kreatif (Ananda \& Susilowati, 2019).

Sebagai bagian dari kekayaan yang dimiliki masyarakat tentu tak dapat dipisahkan perlunya pengambil kebijakan yakni pemerintah untuk ikut berpartisipasi, karena tugas-tugas pemerintahan dibentuk untuk melayani masyarakat, juga dengan majunya ekonomi rakyat artinya masyarakat ikut serta membantu pemerintah dalam pembangunan. Maka berbagai kebijakan di tempuh oleh pemerintah antara lain pemerintah membuat regulasi melalui Undang-Undang No. 20 Tahun 2008 tentang Usaha Mikro, Kecil, dan Menengah (UMKM). Di sana antara lain dimaksudkan agar usaha mikro, kecil dan menengah di tengah masyarakat mendapatkan perlindungan sehingga kegiatan ekonomi masyarakat dapat memberikan kesejahteraan kepada masyarakat itu sendiri, khususnya usaha kuliner yang pada umumnya masih berskala mikro atau kecil. Terkait tujuannya, Rawis, Panelewen, dan Mirah (2016) 
menjelaskan bahwa regulasi ini merupakan usaha untuk memperluas lapangan kerja, pemerataan ekonomi melalui aktivitas peningkatan pendapatan masyarakat.

Tujuan kajian ini adalah untuk memperoleh format solusi atau program pengembangan kuliner tradisional sehingga terdapat kerangka atau model pendekatan secara lebih baik lagi sekaligus memudahkan upaya membangun kuliner tradisional agar memberi kesejahteran bagi pengusaha kecil. Manfaat yang diharapkan adalah dengan adanya kerangka atau model tersebut akan membantu pengusaha kuliner termasuk pemerintah dan berbagai pihak lain dalam membangun usaha kuliner tradisional di masyarakat ke arah yang lebih baik lagi.

\section{METODE PENELITIAN}

Penelitian ini adalah penelitian yang mengkaji hasil-hasil penelitian yang telah dilakukan para peneliti di Indonesia yang mencukupi tujuan penelitian ini, dalam menangani kuliner tradisional dalam periode beberapa tahun terakhir. Jadi, penelitian ini adalah penelitian kualitatif melalui penelusuran hasil-hasil penelitian yang diperoleh pada jurnaljurnal nasional yang telah dipublikasikan. Mengutip Creswell (2008), Raco (2010) bahwa metode penelitian kualitatif berkaitan dengan suatu pendekatan atau penelusuran untuk mengeksplorasi atau memahami suatu gejala sentral. Referensi yang dipilih lalu dikelompokkan ke dalam 2 kelompok besar, yaitu permasalahan kuliner tradisional dan solusi atau program yang ditawarkan. Setelah itu dilakukan pengkodean pada kata atau kalimat yang relevan lalu disusun menjadi 2 gambaran mendasar sebagaimana yang sesuai dengan tujuan yang diharapkan dari kajian ini. Adapun jurnal penelitian yang dikaji adalah yang terbit tahun 2015 hingga tahun 2020.

Guna membantu analisis pada kajian ini, digunakan alat bantu berupa software penelitian kualitatif yang dikenal dengan nama Atlas.ti versi 8 dengan alasan software ini relevan dengan penelitian dan memiliki kelebihan tersendiri. Susilowati (2020) menerangkan bahwa Atlas.ti merupakan alat kerja yang kuat dalam menganalisis data tekstual, grafik, video, audio, dan video, hingga dalam jumlah besar, dengan kelebihan seperti membantu mengatur, menyusun kembali, dan mengelola materi secara kreatif namun sistematis. Lalu, masing-masing dokumen dibaca atau dilakukan review untuk menemukan bagian-bagian penting untuk diberi kode (coding). Bagian dokumen yang terdapat permasalahan maka dikategorikan ke dalam permasalahan, sedang bagian solusi atau program dikelompokkan ke dalam solusi atau program yang dibutuhkan untuk menyelesaikan permasalahan yang ada.

\section{HASIL DAN PEMBAHASAN}

Demi memenuhi tujuan penelitian atau kajian ini maka ditelusuri berbagai dokumen jurnal nasional yang telah diterbitkan sejak tahun 2015 hingga kini. Didapatkan 31 (tiga puluh satu) jurnal penelitian yang relevan dan selanjutnya dikelompokkan pada dua bagian besar dan dilakukan coding menggunakan software Atlas.ti versi 8.

\subsection{Hasil}


Adapun hasil review terkait permasalahan yang dihadapi usaha kuliner tradisional terdapat pada review report penelitian yang selanjutnya ditampilkan hasilnya dalam bentuk organic layout sebagaimana terlihat pada Gambar 1 yang merupakan permasalahan yang dihadapi oleh usaha kuliner tradisional di Indonesia. Dari Gambar 1 terlihat bahwa permasalahan yang dihadapi dalam pengembangan usaha kuliner rakyat cukup banyak, dan berdasarkan network yang diperoleh ada 18 (delapan belas) permasalahan. Kalau dibagi maka ada 2 (dua) permasalahan besar, yaitu permasalahan yang berasal dari usaha kuliner itu sendiri (internal) maupun permasalahan yang harus dihadapi yang berasal dari luar (eksternal). Selanjutnya, terkait solusi atau program, dihasilkan review report dan menampilkan network model organic layout dalam bentuk orthogonal routing sebagaimana terlihat pada Gambar 2. Pada Gambar 2 terdapat 51 (lima puluh satu) solusi atau program yang dihasilkan melalui coding. Dari semua solusi atau program dipecah lagi dalam 3 bagian, yaitu yang harus dilaksanakan oleh pengusaha kuliner sendiri, pemerintah, hingga manfaat yang akan diperoleh.

\subsection{Pembahasan}

Hal yang perlu diketahui pertama kali dalam menyelesaikan setiap masalah adalah memahami dengan baik permasalahannya. Karena itu, kajian ini menekankan juga perlu memahami permasalahan yang dialami dalam pengembangan kuliner tradisional ini. Permasalahan pengelolaan kuliner rakyat yang merupakan kuliner tradisional ini seiring atau sejalan dengan kualitas pengelolaan yang dimiliki oleh masyarakat sendiri dan terutama juga pilihan kebijakan oleh pihak pemerintah dalam mengatasi permasalahan yang ada. 


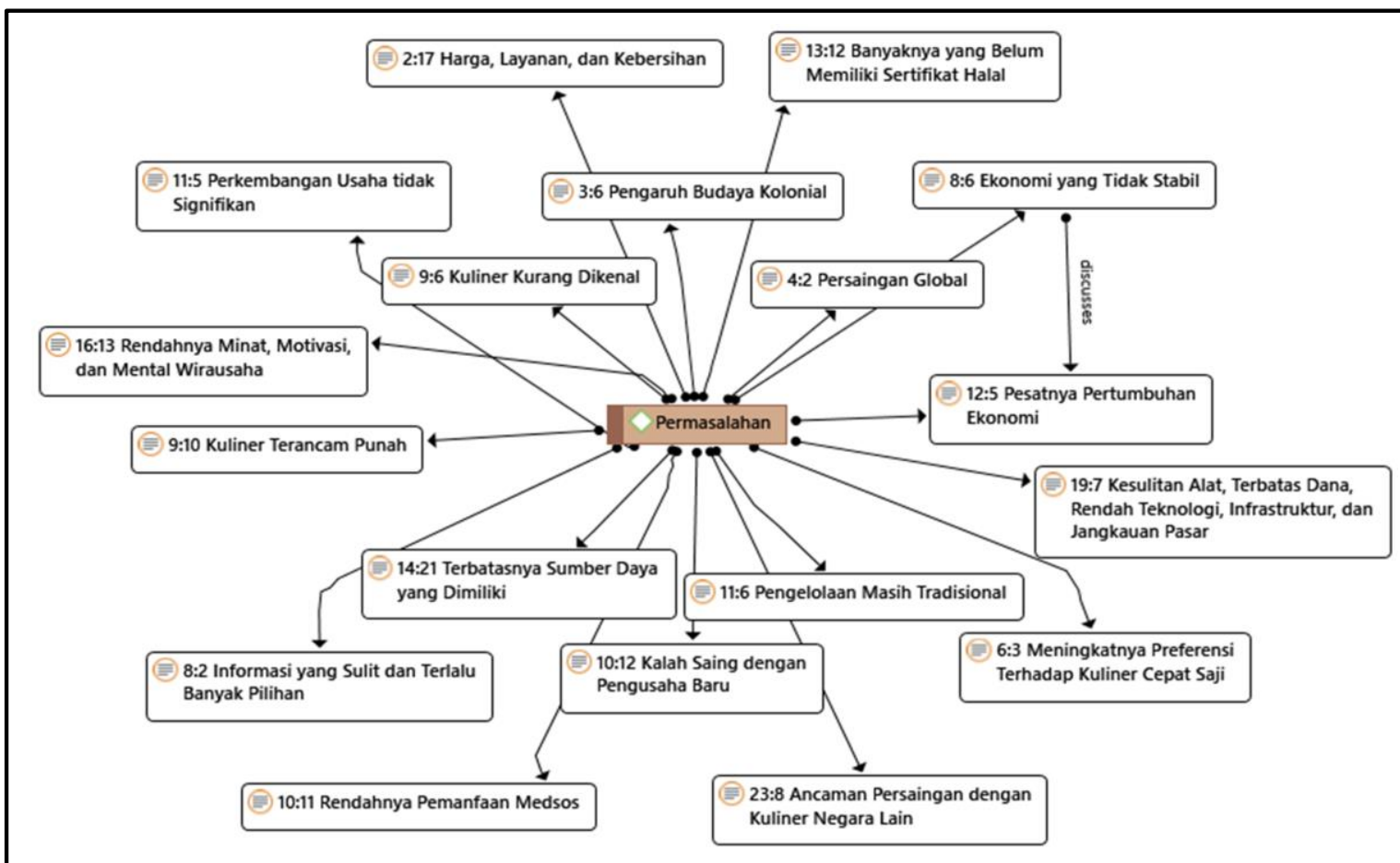

Gambar 1. Permasalahan Kuliner Indonesia

Merujuk kepada Gambar 1, permasalahan kuliner tradisional di Indonesia adalah permasalahan yang sudah ada sejak lama, namun karena belum terselesaikan maka permasalahan tersebut ikut berlarut atau berulang hingga kini. Kalau dibagi, permasalahan yang dihadapi berasal dari internal usaha kuliner itu sendiri, hingga berasal dari kondisi eksternal. Berdasarkan Gambar 1 teridentifikasi bahwa permasalahan internal usaha kuliner tradisional antara lain harga, layanan, dan kebersihan produk dan lokasi (Nariani, 2019), sumber daya yang dimiliki terbatas (Agusetyaningrum, Mawardi, dan Pangestuti, 2016), rendahnya minat, motivasi, dan mental wirausaha (Syarifuddin, Noor, dan Rohendi, 2018), rendahnya pemanfaatan media sosial (Handika, Maradona, dan Dharma, 2018) sebagai sarana teknologi modern guna membantu pemasaran produk, pengelolaan masih tradisional (Abubakar \& Palisuri, 2018), kesulitan alat, akses dana, teknologi, infrastruktur, dan jangkauan pasar (Ananda \& Susilowati, 2019), dan masih banyak yang belum memiliki sertifikat halal (Giyanti \& Indriastiningsih, 2018).

Mengenai permasalahan eksternal tentu saja menjadi tantangan yang tak kalah penting untuk diantisipasi. Permasalahan eksternal antara lain ekonomi yang tidak stabil (Yulianti \& Juwita, 2016) diperparah kondisi masa kini berkenaan dengan pandemi COVID-19 (Hadiwardoyo, 2020), persaingan global (Lestari et al., 2019) yang semakin meningkat, menguatnya preferensi terhadap kuliner cepat saji (Wulandari \& Zubaidah, 2016), dan persaingan dengan pengusaha baru (Handika et al., 2018) yang tak kalah ketat. 


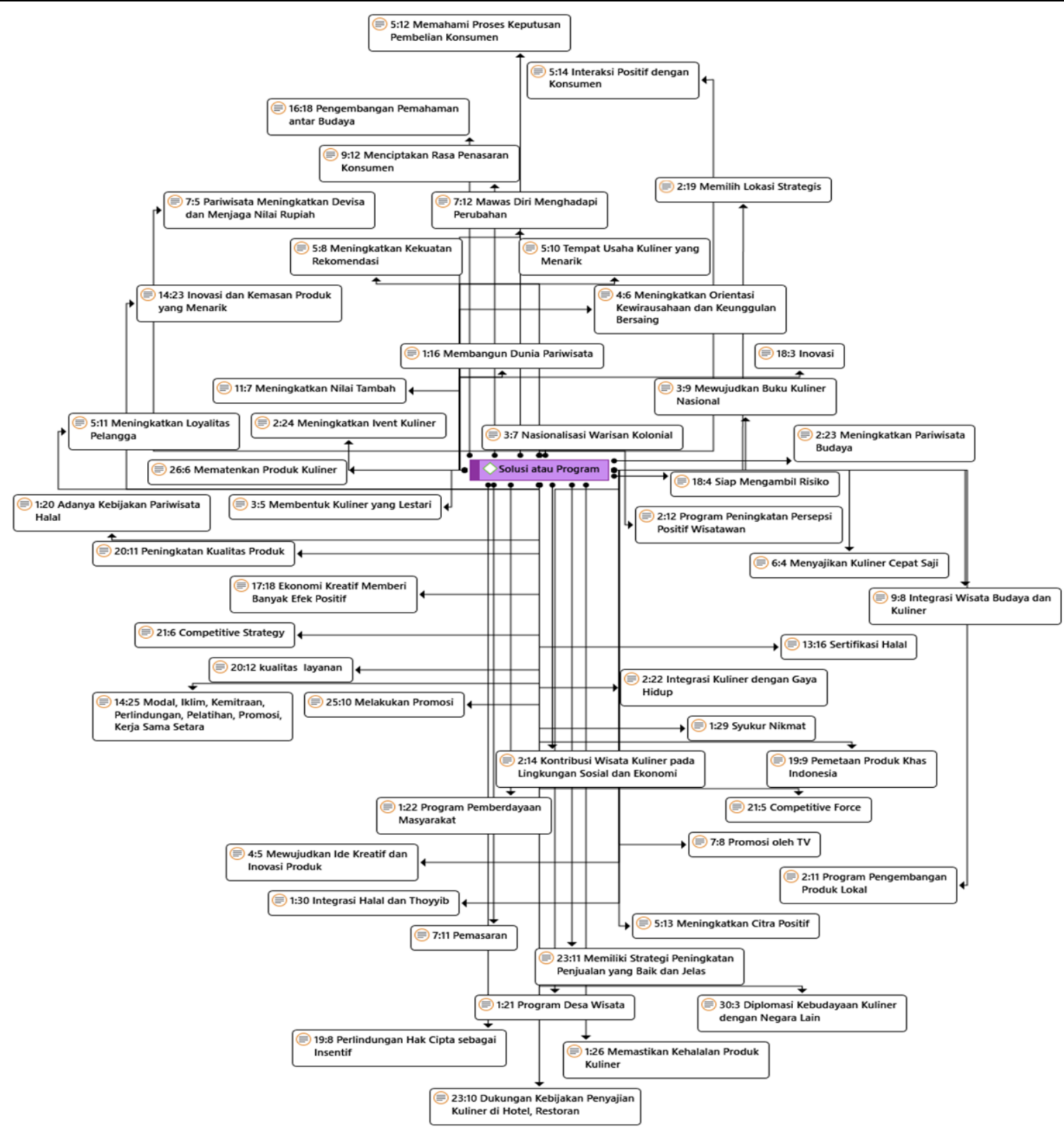

Gambar 2. Solusi atau Program Pengembangan Kuliner Tradisional

Apabila permasalahan yang dihadapi tidak dapat diatasi maka bisa memicu munculnya permasalahan seperti perkembangan usaha kuliner tradisional yang tidak signifikan (Abubakar \& Palisuri, 2018), akan menyebabkan kuliner kurang dikenal hingga terancam punah (Muliani, 2019). Tentu hal ini bukanlah hal yang diinginkan semua pihak. Sehubungan dengan permasalahan yang dihadapi usaha kuliner tradisional ini, maka penelitian ini juga mengidentifikasi solusi atau program yang ditawarkan, sebagaimana tersaji pada Gambar 2 . Adapun solusi atau program yang diidentifikasi terdiri dari kegiatan yang perlu diikuti oleh pelaku usaha kuliner untuk meningkatkan keahlian dan kualitas produk yang dihasilkan, kegiatan yang harus dilakukan oleh pemerintah guna mendukung pengembangan usaha kuliner, serta manfaat yang diperoleh bila usaha kuliner mampu mengangkat kesejahteraan masyarakat kuliner terkait.

Terkait dengan kegiatan yang perlu dilakukan oleh pelaku usaha kuliner agar keterampilan dan kualitas produk meningkat antara lain program peningkatan pemahaman mengenai kualitas produk (Montung, Sepang, dan Adare, 2015) baik melalui pelatihan atau 
studi produk yang berkualitas, peningkatan nilai tambah (Abubakar \& Palisuri, 2018) melakukan variasi produk, inovasi kemasan produk (Agusetyaningrum et al., 2016) (Juliana, 2019), yang menarik dan produk memiliki daya simpan yang lama, kualitas layanan produk (Montung et al., 2015), pendukung pemasaran dalam berbagai bentuk seperti promosi (Tresnawati \& Prasetyo, 2018) baik di televisi (Besra, 2012), kekuatan rekomendasi terutama melalui mulut, interaksi yang positif dengan konsumen (Rinandiyana, Kurniawti, dan Kurniawan, 2017), dan jaminan kehahalan produk kuliner (Darwis, 2017) (Giyanti \& Indriastiningsih, 2018).

Pada masa kini terjadi perubahan gaya hidup konsumen seperti meningkatnya kebutuhan akan makanan cepat saji yang juga perlu melakukan penyesuaian (Wulandari \& Zubaidah, 2016), konsisten menjaga citra positif untuk meningkatkan loyalitas pelanggan (Rinandiyana et al., 2017). Untuk itu, sikap yang perlu dimiliki oleh pelaku usaha kuliner adalah keberanian mengambil risiko (Juliana, 2019), mawas diri menghadapi perubahan (Besra, 2012) sehingga usaha kuliner tetap kuat bertahan dan berkembang (Rahman, 2018), serta satu lagi hal yang sangat penting adalah mensyukuri segala nikmat yang telah diberikan Allah (Darwis, 2017). Selain itu beberapa program yang perlu dilakukan adalah memberi bantuan modal, iklim yang menunjang, kemitraan yang baik, perlindungan, pelatihan, promosi dan kerja sama setara (Agusetyaningrum et al., 2016), penguatan ekonomi kreatif yang menunjang usaha kuliner tradisional (Hutabarat, 2015), dan peningkatan program pemberdayaan masyarakat (Darwis, 2017). Tak ketinggalan adalah usaha kuliner tradisional ini terintegrasi dengan kepariwisataan (Darwis, 2017) yang tentu saja akan memberikan implikasi positif bagi daerah di mana kuliner berasal. Dengan kunjungan wisata baik dalam negeri maupun luar negeri jelas akan ikut serta mengangkat derajat kesejahteraan masyarakat.

Terdapat tren kepariwisataan yang cukup menarik seperti wisata halal yang sudah berkembang di berbagai negara yang bahkan bukan negara dengan tradisi halal sekalipun. Untuk memanfaatkan hal ini dibutuhkan sertifikasi halal produk (Giyanti \& Indriastiningsih, 2018), dan integrasi kuliner halal dengan thoyyib (Darwis, 2017) agar produk juga memenuhi syarat kesehatan. Masih banyak yang dapat dilakukan seperti yang ditunjukkan oleh Gambar 2 sehingga usaha kuliner rakyat tanpa meninggalkan ciri khas sebagai kuliner tradisional, namun dapat bersaing dengan kuliner dari daerah lain. Apaladi di era globalisasi sekarang ini membuka kuliner tradisional rakyat bersaing dengan kuliner dari berbagai negara yang kini sudah beredar di tanah air yang memiliki potensi yang besar untuk menggusur kuliner tradisional.

Pandemi COVID-19 juga menyebabkan permasalahan atau tantangan tersendiri, sehingga langkah yang perlu dilakukan adalah pemberian bantuan atau stimulan agar usaha kuliner bisa tetap bertahan, atau bisa menjadikan situasi pendemi sebagai peluang yang dapat dimanfaatkan. Dengan demikian pengembangan kuliner akan ikut serta meningkatkan penerimaan devisa negara dan menjaga nilai tukar rupiah melalui kontribusi pada dunia pariwisata (Besra, 2012), kontribusi wisata kuliner juga pada lingkungan sosial dan ekonomi (Nariani, 2019), melestarikan kuliner itu sendiri dan khususnya kesejahteraan pada masyarakat kuliner tradisional. 


\section{KESIMPULAN}

Hasil yang diperopleh telah sesuai tujuan kajian ini, dan kesimpulannya adalah:

1. Permasalahan yang dihadapi usaha kuliner tradisional Indonesia terdiri dari permasalahan internal dan eksternal. Permasalahan internal seperti harga, layanan, dan kebersihan produk. Juga lokasi, sumber daya yang dimiliki terbatas, rendahnya minat, motivasi, dan mental wirausaha, rendahnya pemanfaatan media sosial sebagai sarana teknologi modern guna membantu pemasaran produk, pengelolaan masih tradisional, kesulitan alat, akses dana, teknologi, infrastruktur, dan jangkauan pasar, dan masih banyak yang belum memiliki sertifikat halal. Sedangkan permasalahan eksternal antara lain ekonomi yang tidak stabil diperparah kondisi masa kini berkenaan dengan pandemi COVID-19, persaingan global yang semakin meningkat, menguatnya preferensi terhadap kuliner cepat saji, dan persaingan dengan pengusaha baru yang tak kalah ketat.

2. Solusi atau program yang ditawarkan antara lain program pelatihan atau studi produk yang berkualitas, peningkatan nilai tambah melakukan variasi produk, inovasi kemasan produk, kualitas layanan produk, promosi, interaksi yang positif dengan konsumen, dan jaminan kehahalan produk. Selain itu perlu ada keberanian mengambil risiko, mawas diri menghadapi perubahan sehingga usaha kuliner tetap kuat bertahan dan berkembang, serta mensyukuri segala nikmat yang telah diberikan Allah. Dari pemerintah perlu ada bantuan modal, iklim yang menunjang, kemitraan yang baik, perlindungan, pelatihan, promosi dan kerja sama setara, penguatan ekonomi kreatif, serta peningkatan program pemberdayaan masyarakat misalnya melalui integrasi dengan kepariwisataan.

Meski demikian penelitian ini masih memiliki keterbatasan dan dibutuhkan kajian lebih lanjut. Kajian yang diperlukan untuk pengembangan lebih lanjut antara lain perlunya peran dan kontribusi yang lebih spesifik dan terukur dari berbagai pihak, dan desain peran masingmasing dalam membangun usaha kuliner tradisional agar mampu meningkatkan kesejahteraan pelaku usaha kecil di Indonesia secara berkelanjutan.

\section{DAFTAR PUSTAKA}

Abubakar, H., \& Palisuri, P. (2018). Karakteristik Wirausaha Terhadap Keberlanjutan Industri Kuliner Tradisonal. Seminar Nasional dan Call for Paper: Manajemen, Akuntansi dan Perbankan, 403-410.

Agusetyaningrum, V., Mawardi, M., \& Pangestuti, E. (2016). Strategi Pengembangan Usaha Kecil dan Menengah (UKM) untuk Meningkatkan Citra Kota Malang sebagai Destinasi Wisata Kuliner (Studi Kasus pada UKM Berbasis Kuliner Kota Malang). Jurnal Administrasi Bisnis S1 Universitas Brawijaya, 38(2), 105-111.

Aini, A. I., Khaudli, M. I., \& Suprapto, R. (2018). Pemberdayaan Ekonomi Masyarakat melalui Pemasaran Wisata Kuliner Jajanan Tradisional di Desa Cantuk Kabupaten Banyuwangi. ENGAGEMNT; Jurnal Pengabdian Kepada Masyarakat, 2(2), 168-175. https://doi.org/http://dx.doi.org/10.29138/engagement.v2i2.74.

Alamsyah, Y. (2008). Bangkitnya Bisnis Kuliner Tradisional. PT Elex Media Komputindo. Jakarta. 
Ananda, A. D., \& Susilowati, D. (2019). Pengembangan Usaha Mikro Kecil dan Menengah (UMKM) Berbasis Industri Kreatif di Kota Malang. Jurnal Ilmu Hukum dan Ilmu Ekonomi, X(X), 120-142.

Besra, A. (2012). Potensi Wisata Kuliner dalam Mendukung Pariwisata di Kota Padang. Riset Akuntansi dan Bisnis, 12, 74-101.

Darwis, R. (2017). Inventarisasi Khazanah Kuliner Tradisional Desa Pakuwon Kecamatan Cisurupan Kabupaten Garut dalam Konteks Pembangunan Kampung Wisata Halal. Tourism Scientific Journal, 2(2), 234. https://doi.org/10.32659/tsj.v2i2.31.

Fajri, I. (2018). Strategi Peningkatan Penjualan Makanan Tradisional Sunda Melalui Daya Tarik Produk Wisata Kuliner di The Jayakarta Bandung Suite Hotel \& Spa. THE Journal: Tourism and Hospitality Essentials Journal, 8(1), 45. https://doi.org/10.17509/thej.v8i1.11689.

Giyanti, I., \& Indriastiningsih, E. (2018). Pemetaan UKM Kuliner Kota Surakarta Berdasarkan Status Sertifikasi Halal. Jurnal Teknologi, 11, 87-91. http://dx.doi.org/10.1080/08974438.2013.723997.

Hadiwardoyo, W. (2020). Kerugian Ekonomi Nasional Akibat Pandemi Covid-19. Baskara: Journal of Business and Entrepreneurship. https://doi.org/10.24853/baskara.2.2.83-92.

Hamidah, S. (2009). Analisis Kebijakan Linkage Program. 185-216.

Handika, M. R., Maradona, A. F., \& Dharma, G. S. (2018). Strategi Pemasaran Bisnis Kuliner Menggunakan Influencer Melalui Media Sosial Instagram. Manajemen dan Bisnis Undiknas, 15(2), 192-203.

Herawati, H. (2008). Penentuan Umur Simpan pada Produk Pangan. Jurnal Litbang Pertanian, 27(4), 124-130.

Hubeis, M., Purwanto, B., Dewi, F. R., Widyastuti, H., \& Febtyanisa, M. (2015). Strategi Pengembangan UMKM Pangan yang Berdaya Saing di Indonesia. Prosiding Seminar Hasil-Hasil PPM, I(1), 126-143.

Hutabarat, L. R. F. W. M. (2015). Strategi Pengembangan Usaha Kuliner di Kota Malang Berbasis Ekonomi Kreatif. Jurnal Ekonomi Dan Studi Pembangunan, 7(1), 12-20.

Juliana, J. (2019). Pengaruh Inovasi dan Pengambilan Risiko Terhadap Perkembangan Wirausaha Muda dalam Bidang Kuliner di Wilayah Binong Tangerang. Khasanah Ilmu Jurnal Pariwisata Dan Budaya, 10(1). https://doi.org/10.31294/khi.v10i1.5623.

Katadata. (2018). Industri Makanan dan Minuman Tumbuh di Atas PDB Nasional. Katadata News and Research. https://databoks.katadata.co.id/datapublish/2018/01/30/industrimakanan-dan-minum-tumbuh-di-atas-pdb-nasional.

Lestari, I., Astuti, M., \& Ridwan, H. (2019). Pengaruh Inovasi dan Orientasi Kewirausahaan Terhadap Keunggulan Bersaing Umkm Kuliner. Jurnal Riset Manajemen dan Bisnis (JRMB) Fakultas Ekonomi UNIAT, 4(1), 111-118. https://doi.org/10.36226/jrmb.v4i1.245.

Montung, P., Sepang, J., \& Adare, D. (2015). Pengaruh Kualitas Produk, Kualitas Layanan 
dan Persepsi Harga Terhadap Kepuasan Pelanggan di Restoran Kawan Baru. Jurnal Berkala Ilmiah Efisiensi, 15(5), 678-689.

Muliani, L. (2019). Potensi Bubur Ase sebagai Daya Tarik Wisata Kuliner Jakarta. Destinesia: Jurnal Hospitaliti dan Pariwisata, 1(1), 49-56. https://doi.org/10.31334/jd.v1i1.485.

Nariani, N. K. (2019). Pengembangan Kuliner Lokal Berdasarkan Persepsi Wisatawan di Ubud, Bali. Journey (Journal of Tourismpreneurship, Culinary, Hospitality, Convention and Event Management), 1(2), 85-98.

Pamungkas, D. P. (2016). Sistem Informasi Kuliner di Indonesia ( Studi Kasus: Kulina . id ). Electronics, Informatics, and Vocational Education (ELINVO), 1(2), 118-127.

Prayogi, D. (2017). Pengembangan Potensi Wisata Kuliner Kota Malang berbasis Sumber Daya Lokal. Pesona, 2(01), 1-13.

Purwaning, A. S. (2017). Identifikasi Kuliner Lokal Indonesia dalam Pembelajaran Bahasa Inggris. Jurnal Pariwisata Terapan, 1(2), 38. https://doi.org/10.22146/jpt.24970.

Putra, A. A. G. B., Fredlina, K. Q., Satwika, I. P., \& Ardiyanti, A. A. A. P. (2020). Model Aplikasi Ensiklopedia Kuliner Tradisional Bali Berbasis Mobile Geographical Information System. Jutisi: Jurnal Ilmiah Teknik Informatika Dan Sistem Informasi, 9(1), 95-106.

Raco, J. (2010). Metode Penelitian Kualitatif: Jenis, Karakteristik dan Keunggulannya. https://doi.org/10.31219/osf.io/mfzuj.

Rahman, F. (2018). Kuliner sebagai Identitas Keindonesiaan. Jurnal Sejarah, 2(1), 43-63. https://www.kompasiana.com/zulfikarali/55280b8af17e6119088b45a7/kuliner-sebagaiidentitas-budaya\%0Afile:///C:/Users/User/Downloads/fvm939e.pdf.

Rawis, J. E. O., Panelewen, V. V. J., \& Mirah, A. D. (2016). Analisis Keuntungan Usaha Kecil Kuliner dalam Upaya Pengembangan UMKM di Kota Manado (Studi Kasus Usaha Katering Miracle Ranotana Weru). Jurnal Riset Ekonomi, Manajemen, Bisnis, dan Akuntansi, 4(2), 106-119. https://doi.org/10.35794/emba.v4i2.12527.

Ri'aeni, I. (2019). Strategi Komunikasi Pemasaran Digital pada Produk Kuliner Tradisional. LUGAS Jurnal Komunikasi, 1(2), 141-149. https://doi.org/10.31334/ljk.v1i2.443.

Rinandiyana, L. R., Kurniawati, A., \& Kurniawan, D. (2017). Analisis Faktor-Faktor yang Mempengaruhi Keputusan Pembelian oleh Generasi Milenial pada Industri Kuliner di Kota Tasikmalayar $\quad 3(\mathrm{Mei}), \quad 18-27$. http://jurnal.unsil.ac.id/index.php/jem/article/view/322.

Sukerti, N. W., Marsiti, C. I., \& Suriani, N. M. (2016). Reinventarisasi Makanan Tradisional Buleleng sebagai Upaya Pelestarian Seni Kuliner Bali. Jurnal Ilmu Sosial dan Humaniora, 5(1), 744-753. https://doi.org/10.23887/jish-undiksha.v5i1.8282.

Sulastri, H., Hasniah, \& Suraya, R. S. (2019). TRADITIONAL CULINARY TOUR IN BERTI BEACH OF KOLAKA. Etnoreflika: Jurnal Sosial Dan Budaya, 8, 246-252. https://doi.org/https://doi.org/10.33772/etnoreflika.v8i3.815. 
Susilowati, I. (2020). Modul Penelitian Kualitatif dengan Atlas.ti. Universitas Diponegoro. Semarang.

Syarifuddin, D., Noor, C. M., \& Rohendi, A. (2018). Memaknai Kuliner Lokal sebagai Daya Tarik Wisata Kota Bandung. Pengabdian Kepada Masyarakat, 1(1), 55-64.

Tresnawati, Y., \& Prasetyo, K. (2018). Pemetaan Konten Promosi Digital Bisnis Kuliner Kika's Catering di Media Sosial. PRofesi Humas: Jurnal Ilmiah Ilmu Hubungan Masyarakat, 3(1), 102. https://doi.org/10.24198/prh.v3i1.15333.

Widowati, I., Hartati, \& Amirudin, Z. (2018). Kemasan Makanan Kuliner Tradisional “ Megono " sebagai Upaya Memperpanjang Waktu Simpan. Jurnal Litbang Kota Pekalongan, 15, 17-25.

Wulandari, E., \& Zubaidah, E. (2016). Kebab Bakso Bakar: Inovasi Kuliner Khas Kota Malang. Jurnal Pangan dan Agroindustri Vol . 4 No 1 p . 230-237.

Yulianti, E., \& Juwita, F. (2016). Sistem Pendukung Keputusan Pemilihan Tempat Kuliner di Kota Padang Menggunakan Metode Perbandingan Eksponensial (MPE). Jurnal TEKNOIF, 4(2), 51-58. 